\title{
A novel Epstein-Barr virus-latent membrane protein-1-specific T-cell receptor for TCR gene therapy
}

Hyun-II Cho ${ }^{*, 1,2}$, Un-Hee Kim ${ }^{1}$, A-Ri Shin ${ }^{1,2}$, Ji-Na Won ${ }^{1}$, Hyun-Joo Lee ${ }^{1}$, Hyun-Jung Sohn ${ }^{1}$ and Tai-Gyu Kim*,1,2,3

${ }^{1}$ Catholic Hematopoietic Stem Cell Bank, College of Medicine, The Catholic University of Korea, Seoul 06591, South Korea; ${ }^{2}$ Catholic Cancer Research Institute, College of Medicine, The Catholic University of Korea, Seoul 06591, South Korea and ${ }^{3}$ Department of Microbiology and Immunology, College of Medicine, The Catholic University of Korea, Seoul 06591, South Korea

Background: Adoptive transfer of genetically engineered T-cells to express antigen-specific T-cell receptor (TCR) is a feasible and effective therapeutic approach for numerous types of cancers, including Epstein-Barr virus (EBV)-associated malignancies. Here, we describe a TCR gene transfer regimen to rapidly and reliably generate T-cells specific to EBV-encoded latent membrane protein-1 (LMP1), which is a potential target for T-cell-based immunotherapy.

Methods: A novel TCR specific to LMP1 (LMP1-TCR) was isolated from HLA-A*0201 transgenic mice that were immunised with the minimal epitope LMP1 166 (TLLVDLLWL), and LMP1-TCR-transduced peripheral blood lymphocytes were evaluated for functional specificities.

Results: Both human CD8 and CD4 T-cells expressing the LMP1-TCR provoked high levels of cytokine secretion and cytolytic activity towards peptide-pulsed and LMP1-expressing tumour cells. Notably, recognition of these T-cells to peptide-pulsed cells was maintained at low concentration of peptide, implying that the LMP1-TCR has high avidity. Infusion of these engineered T-cells revealed remarkable therapeutic effects and inhibition of tumour growth in a preclinical xenogeneic model. We observed explosive ex vivo proliferation of functional TCR-transduced T-cells with artificial antigen-presenting cells that express costimulatory molecules CD80 and 4-1BBL.

Conclusions: These data suggest that the novel TCR-targeting LMP1 might allow the potential design of T-cell-based immunotherapeutic strategies against EBV-positive malignancies.

Significant progress in cancer immunology has been made in understanding the roles of tumour-reactive T-cells that can recognise and destroy malignant cells. Over the years, adoptive transfer of antigen-specific T-cells, mainly cytotoxic CD8 T-cells, has been applied as a safe and robust immunotherapeutic procedure in patients to eliminate malignant cells and extend survival without major complications (Riddell and Greenberg, 1995; Rosenberg et al, 2008).

Epstein-Barr virus (EBV) is associated with a broad range of malignancies that are distinguished by three distinct patterns of viral latency-related gene expression. Most successful clinical outcomes were obtained with EBV-specific cytotoxic T-cells against post-transplant lympho-proliferative disease, which expresses the complete array of EBV-latency-III antigens in transplant recipients (Gottschalk et al, 2005). However, EBVpositive nasopharyngeal carcinoma, Hodgkin's lymphoma (HL), and NK/T-cell lymphoma typically express more limited and weakly immunogenic EBV-latency-II antigens including latent membrane protein 1 (LMP1) and LMP2. Particularly, LMP1 is a transmembrane oncoprotein that mimics the tumour TNF receptor

*Correspondence: Professor H-I Cho; E-mail: hyun.cho@catholic.ac.kr or Professor T-G Kim; E-mail: kimtg@catholic.ac.kr

Received 13 October 2017; revised 1 December 2017; accepted 1 December 2017; published online 23 January 2018

(C) 2018 Cancer Research UK. All rights reserved 0007-0920/18 
family members, capable of immortalising B-cells, and enhances cell survival by increasing bcl-2 activity (Graham et al, 2010; Pratt et al, 2012). Supported by this, although it is sometimes of low expression or absent (Kanemitsu et al, 2012), LMP1 has been proposed as an attractive target antigen for T-cell-based immunotherapy against EBV latency-II malignancies. Numerous reports have shown that T-cells specific for the EBV-latency-II antigens in patients are usually functionally impaired (Gandhi et al, 2007; Li et al, 2007) or suppressed in tumour microenvironments (Yamamoto et al, 2008; Fogg et al, 2013) and present in low frequency (Fogg et al, 2009), but also possessing the therapeutic potency and the capacity to be expanded with EBV-latency-II antigens-loaded antigen-presenting cells (APCs) in vitro (Straathof et al, 2005; Smith et al, 2006). Thus, several groups, including ours, have developed in vitro stimulation protocols to facilitate the generation of LMP1- and LMP2-specific T-cells and have demonstrated objective long-lasting clinical responses (Bollard et al, 2014; Cho et al, 2015b).

Despite their safety and apparent clinical effectiveness, there are significant drawbacks for in vitro expansion of EBV-specific T-cells, such as the relatively long manufacturing time, limited availability, and comparably low avidity of effector T-cells. Considering this, several groups have developed genetically engineered T-cells with an extrinsic antigen-specific T-cell receptor (TCR) or a chimeric antigen receptor (CAR) as an alternative approach to rapidly manufacture large numbers of potent tumourreactive effector cells. Particularly, the clinical efficacy of TCRengineered T-cells has been successfully demonstrated in patients with melanoma, synovial cell sarcoma, and multiple myeloma using MART1- and/or NY-ESO1-specific TCR (Morgan et al, 2006; Robbins et al, 2011; Rapoport et al, 2015), similar to CD19targeted CAR-T-cells in patients with B-cell haematologic malignancies (Porter et al, 2011; Lee et al, 2015). Likewise, numerous groups have attempted to develop EBV-targeting engineered T-cells, either with CAR targeting CD30 (Savoldo et al, 2007) and CD70 (Shaffer et al, 2011), or with extrinsic TCR specific to EBV nuclear antigen 3 (Schaft et al, 2006) and LMP2a (Frumento et al, 2013; Xue et al, 2013; Zheng et al, 2015). However, although LMP1 is considered as an attractive target to treat EBVpositive malignancies, T-cells engineered with LMP1-specific TCR have not been developed. Here, we report the functionality and specificity of a novel murine TCR, which recognises an LMP1derived epitope presented by HLA-A ${ }^{\star} 0201$ molecules. Mainly, we demonstrate that potent EBV-LMP1-specific T-cells can be efficiently generated by TCR gene transfer and exponentially expanded in vitro with artificial APCs regimen, suggesting potential applications in T-cell-based immunotherapy against EBV-associated diseases, including EBV-latency-II malignancies.

\section{MATERIALS AND METHODS}

Mice. Full-length HLA-A ${ }^{\star} 0201$-expressing transgenic (HLA-A2 Tg) mice (C57BL/6-Tg(HLA-A2.1)1Enge/J) and NSG mice (NOD.Cg-Prkd ${ }^{\text {cscid }}$ Il $2 \mathrm{rg}^{\text {tm1Wjl }} /$ SzJ) were obtained from the Jackson Laboratory (Bar Harbor, ME, USA). Animal experiments were performed in accordance with our institutional animal care committee guidelines.

Cell lines. K562, Jurkat, T2, and 293T cells were obtained from the American Type Culture Collection (Manassas, VA, USA). EBVtransformed B-lymphoblastoid cell lines (LCLs) were prepared with EBV B95-8 strain and HLA-A subtypes were determined with sequence-based typing. For K562-based transfectants, HLA-

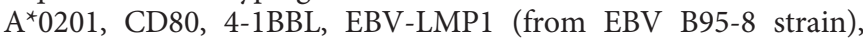
and firefly-luciferase $\mathrm{cDNA}$ were cloned into the lentiviral vector pCDH-EF1 (System Bioscience, Palo Alto, CA, USA). K562 cells were first transduced with HLA-A ${ }^{\star} 0201$ (K-A2). Then, K-A2 cells were transduced with EBV-LMP1 $\left(\mathrm{K}-\mathrm{A} 2_{\mathrm{LMP}}\right)$ and sequentially firefly-luciferase (K-A2 $\left.2_{\text {LMP1/LUC }}\right)$. K-A2 cells were also transduced with human CD80 and 4-1BBL for artificial APCs (K-A2 $80 / 4-1 \mathrm{BBL})$. Stably viable clones were isolated with limiting dilutions, and gene expression was verified by immunohistochemical analysis or flow cytometry.

Peptides and reagents. Synthetic peptides representing CD8 T-cell epitopes $\mathrm{WT}_{126}$ (RMFPNAPYL), LMP1 $1_{32}$ (LLLALLFWL), $\mathrm{LMP1}_{92}$ (LLLIALWNL), LMP1 $1_{125}$ (YLLEMLWRL), LMP1 $1_{159}$ (YLQ QNWWTL), LMP1 $1_{166}$ (TLLVDLLWL), LMP1 $1_{167}$ (LLVDLLWLL), and LMP $_{173}$ (WLLLFLAIL) at $>85 \%$ purity were purchased from A\&A Labs (San Diego, CA, USA). Monoclonal anti-mouse CD40 (FGK45.5) was from BioXCell (West Lebanon, NH, USA). High molecular-weight Poly-IC was from InvivoGen (San Diego, CA, USA), and recombinant cytokines were from Peprotech (Rocky Hill, NJ, USA). Fluorescence-conjugated antibodies were obtained from eBioscience (San Diego, CA, USA).

Immunisation and T-cell clones. To generate $\mathrm{LMP} 1_{166^{-}}$specific CD8 T-cells, HLA-A2 Tg mice were immunised intravenously with $2 \times 10^{6}$ dendritic cells (DCs) pulsed with $10 \mu \mathrm{g} \mathrm{ml}^{-1} \mathrm{LMP}_{166}$ for $18 \mathrm{~h}$, and after 7 days, the mice received an intravenous TriVaximmunisation. TriVax consists of a mixture of $150 \mu \mathrm{g} \mathrm{LMP} 1_{166}$, $50 \mu \mathrm{g}$ poly-IC, and $100 \mu \mathrm{g}$ anti-CD40 antibodies. Eight days after the booster-immunisation, intracellular IFN $\gamma$-staining was performed to measure the frequency of LMP $1_{166}$-specific cytokinesecreting CD8 T-cells. LMP1 $1_{166}$-specific T-cell cloning was carried out by following procedures with minor modification as described (Chinnasamy et al, 2011; Rosati et al, 2014). Briefly, $1.5 \times 10^{6} \mathrm{CD} 8$ T-cells isolated from spleen were co-cultured with $5 \times 10^{5}$ irradiated (6000 cGy) DCs pulsed with $5 \mu \mathrm{g} \mathrm{ml}^{-1} \mathrm{LMP}_{166}$ in 24well plate. Seven days later, IFN $\gamma$-EliSpot assays were performed. Bulk cultured T-cells were cloned at single cells per well in U-bottom 96-well plates with $3 \times 10^{4} \mathrm{LMP1}_{166}$-pulsed irradiated (10000cGy) T2 and $1 \times 10^{5}$ irradiated (5000 cGy) splenocytes in medium containing $50 \mathrm{IU} \mathrm{ml}^{-1}$ IL-2 and $5 \mathrm{ng} \mathrm{ml}^{-1}$ IL-7. Proliferating T-cell clones were evaluated for responsiveness towards $\mathrm{LMP}_{166}$ using intracellular IFN $\gamma$-staining.

Cloning of LMP1-specific, HLA-A ${ }^{\star} \mathbf{0 2 0 1 - r e s t r i c t e d ~ T C R . ~ T o t a l ~}$ RNA from $\mathrm{T}$-cell clones was isolated using an RNeasy-mini kit (Qiagen, Valencia, CA, USA), and TCR $\alpha / \beta$ genes were amplified using SMART-RACE cDNA-amplification kit (Clontech, Mountain View, CA, USA) according to the manufacturer's instructions with primers in the constant region of mouse TCR $\alpha$ and TCR $\beta$ chains (Chinnasamy et al, 2011) and sequenced. Amplified TCR $\alpha$ / $\beta$ genes were linked using two-step overlapping-PCR with primers; TCR $\alpha$-reverse; $5^{\prime}$-cttccacgtcgccggcctgcttcagcagggagaagttggtggcgccg ctgcctctcttcactctactggaccacagcctcagcgt- $3^{\prime}$; TCR $\beta$-reverse; $5^{\prime}$-ttctcc ctgctgaagcaggccggcgacgtggaagaaaaccctggcccc- $3^{\prime}$ encoding furinsensitive spacer RVKRGSG-P2A ribosomal-skip sequence ATNFSLLKQAGDVEENPGP. The full-length modified TCRcDNA was cloned into pCDH-EF1 and sequenced.

Production and transduction of murine TCRs to peripheral blood lymphocytes. The use of human material was reviewed and approved by our Institutional Review Board. 293T-cells $\left(8 \times 10^{6}\right.$ cells) were seeded in a $100-\mathrm{mm}$ plate. Twenty hours later, $12 \mu \mathrm{g}$ cloned pCDH-EF1 and packaging plasmids $(8 \mu \mathrm{g}$ psPAX2, $4 \mu \mathrm{g}$ pMD2G) were simultaneously transfected using $50 \mu \mathrm{l}$ lipofectamine-2000 (Invitrogen, Carlsbad, CA, USA), according to the manufacturer's instructions. Two days later, lentiviruses were harvested and titrated into $293 \mathrm{~T}$ cells. Peripheral blood lymphocytes (PBLs) were isolated from HLA-A2-positive healthy volunteers. For pre-activation, $1 \times 10^{6} \mathrm{PBLs}$ were cultured with anti-CD3/CD28-coated beads (1:1 ratio; Invitrogen) and $300 \mathrm{IU} \mathrm{ml}^{-1} \mathrm{IL}-2$ for 2 days. Lentiviruses encoding murine TCR 
$(\mathrm{MOI}=0.5)$ were added to the activated $5 \times 10^{5}$ PBLs or Jurkat cells, and centrifugation was performed at $2500 \mathrm{rpm}$ for $1 \mathrm{~h}$ at $25^{\circ} \mathrm{C}$ with $8 \mu \mathrm{g} \mathrm{ml}^{-1}$ polybrene (Sigma-Aldrich, St Louis, MO, USA). Peripheral blood lymphocytes prepared identically without transducing murine TCR were referred as a mock-transduced control ( $\left.\mathrm{PBL}^{\text {mock }}\right)$. Two days later, PBLs were evaluated for surface expression and functional specificity of murine TCRs, and used in most experiments.

Flow cytometry analysis. For HLA-A2:immunoglobulin (Ig) dimer staining, Dimer-X reagent (BD Bioscience, San Diego, CA, USA) was prepared; $1 \mu \mathrm{g}$ dimer, $5 \mu \mathrm{g} \mathrm{LMP}_{166}$, and $0.5 \mu \mathrm{g}$ $\beta 2$-microglobulin (Sigma-Aldrich) at $37^{\circ} \mathrm{C}$ overnight. TCRtransduced PBLs $\left(1 \times 10^{6}\right.$ cells $)$ were incubated with $\mathrm{LMP}_{166^{-}}$ loaded HLA-A2:Ig dimer for $40 \mathrm{~min}$, and washed/stained with anti-human CD8a, CD4, and anti-mouse IgG1 for $20 \mathrm{~min}$. For murine TCRs and in vivo persistence, $1 \times 10^{6}$ viable cells were stained with $0.5 \mu \mathrm{g}$ indicated antibodies for $20 \mathrm{~min}$. Fluorescence was measured using a FACS Calibur (BD Biosciences) and analyzed using FlowJo software (Tree Star, Otlen, Switzerland).

Ex vivo expansion and evaluation of TCR-transduced cells. TCR-transduced CD8 and CD4 T-cells were isolated using MACS isolation kits (Miltenyi Biotec, Bergisch Gladbach, Germany), with $>90 \%$ purity. TCR-transduced cells $\left(1 \times 10^{6}\right.$ cells $)$ were cocultured with $5 \times 10^{5}$ peptide-loaded K-A2 $2_{80 / 4-1 B B L}$ with $500 \mathrm{IU} \mathrm{ml}^{-1} \mathrm{IL}-2$. The artificial APCs were loaded with either $5 \mu \mathrm{g} \mathrm{ml}^{-1} \mathrm{LMP}_{166}$ or WT1 $1_{126}$ for $6 \mathrm{~h}$ and irradiated (10 $000 \mathrm{cGy}$ )/ washed before co-culturing. For comparison, cells were incubated with anti-CD3/CD28-coated beads (1:1 ratio). Growing cells were split every 3-4 days and re-stimulated after a 7-day interval under the same conditions. For cytokine-secretion, $5 \times 10^{5}$ engineered cells were co-cultured with irradiated (10000 cGy) peptide-pulsed targets ( $1: 1$ ratio). After 2 days, cytokines in the supernatant were determined with an ELISA kit (eBioscience). For peptide-pulsing, target cells were incubated with $1 \mu \mathrm{g} \mathrm{ml}{ }^{-1}$ peptide for $6 \mathrm{~h}$ at $37^{\circ} \mathrm{C}$. For antigen recognition, IFN $\gamma$-EliSpot assays were performed for peptide-pulsed T2 target cells (Cho et al, 2015b). For cytotoxicity determinations, conventional 5-h chromium-release assays were performed using various target cells.

In vivo therapeutic antitumour experiments. NSG mice (6-8 weeks-old) were sublethally (300 cGy) irradiated on day -1 . Each mouse intravenously received $3 \times 10^{6} \mathrm{~K}-\mathrm{A} 2_{\mathrm{LMP} 1 / \mathrm{LUC}}$ tumour cells. Seven days later, each mouse was three times intravenously infused with $2 \times 10^{7}$ engineered PBLs at every 2-day interval (on day 7, 9, and 11). Intraperitoneal administration of IL-2 (1000 IU per mouse) was given on days $7,9,11,13,15$, and 17 . Tumour growth was monitored weekly by luciferase signal of bioluminescence imaging using Xenogen in vivo imaging system (Caliper Life sciences, Hopkinton, MA, USA). On day 20, peripheral blood samples were analysed to assess in vivo persistence of infused cells.

Statistical analyses. Statistical significance for tumour growth by bioluminescence intensity was determined using two-way ANOVA test, and survival analysis was established by Kaplan-Meier curves using log-rank tests. Results are representative of data obtained from at least two independent experiments. All analyses were performed and graphs were prepared using Prism 5.01 software (GraphPad).

\section{RESULTS}

Isolation of HLA-A2-restricted LMP1 $1_{166}$-specific murine TCR from CD8 T-cell clones. First, we generated EBV-specific CD8 T-cells in HLA-A2-Tg mice with the minimal epitope LMP1 $1_{166}$ (TLLVDLLWL) using a novel vaccination strategy with $L M P 1_{166^{-}}$ loaded DCs followed by a mixture of $\mathrm{LMP}_{166}$ peptides, poly-IC adjuvant, and costimulatory anti-CD40 antibodies (TriVax). TriVax immunisation was highly efficient in stimulating and expanding antigen-specific CD8 T-cells that were primed with antigen-loaded DCs in mice (Cho et al, 2015a). LMP1 $1_{166}$-TriVax booster-immunisation after priming with $\mathrm{LMP}_{166}$-loaded DCs yielded $0.5-1.5 \% \quad$ IFN $\gamma$-producing CD8 T-cells in spleen (Figure $1 \mathrm{~A})$. To generate $\mathrm{LMP} 1_{166}$-specific T-cell clones, purified CD8 T-cells were co-cultured with LMP $_{166}$-loaded DCs for 7 days, and functional activity of in vitro stimulated T-cells was evaluated. As shown in Figure 1B, HLA-A2-restricted CD8 T-cell recognition was evident not only against peptide-pulsed $\mathrm{T} 2$ but also against HLA-A2-positive LCLs (LCL-A2 ${ }^{\text {pos}}$ ), where higher levels of T-cell responses were observed against un-pulsed or $\mathrm{WT} 1_{126}$-pulsed LCL-A2 ${ }^{\text {pos }}$ than against LMP1 $1_{166}$-pulsed HLA-A2negative LCLs (LCL-A2 ${ }^{\text {neg }}$ ). Subsequently, CD8 T-cells were cloned by limited dilution, and proliferative $\mathrm{T}$-cell clones were examined for $\mathrm{LMP} 1_{166}$-specific IFN $\gamma$-producing reactivity (Figure $1 \mathrm{C}$ ). TCR $\alpha$ and TCR $\beta$ chains from each high level of IFN $\gamma$-secreting T-cell clones against $\mathrm{LMP} 1_{166}$ were amplified. Since TCRs consist of heterodimers, isolated TCR $\alpha$ and TCR $\beta$ chains were linked with furin-spacer RVKRGSG-P2A element to express as a single open reading frame, and inserted into lentiviral vector. To examine the surface expression of murine TCRs, Jurkat cells and pre-activated PBLs were transduced with murine TCRs (named S4-1, S4-6, and S4-12). Although each TCR gene was isolated from highly antigenresponding T-cell clones, levels of transduced TCR expression varied. Above all, Jurkat cells and PBLs transduced with TCR S412 , which comprises TRAV3D ${ }^{\star} 02$ and TRBV $26^{\star} 01$ (Supplementary Figure S1), exhibited more than $60 \%$ and $30 \%$ of surface expression, respectively (Figure 1D). To examine TCR functionality, engineered PBLs were co-cultured with $\mathrm{LMP}_{166^{-}}$ pulsed T2 and the concentration of cytokines in the supernatant was measured. TCR S4-12-expressing PBLs secreted high levels of IL-2 against $\mathrm{LMP} 1_{166}$-pulsed targets in comparison to $\mathrm{PBL}^{\text {mock }}$, which were identically prepared without transferring murine TCR (Figure 1E). Jurkat cells transduced with TCR S4-12 also exhibited comparable LMP $1_{166}$-specific IL-2 production (data not shown). Hence, TCR S4-12 was chosen for further studies.

Functional specificities of HLA-A2-restricted LMP1 $1_{166}$-specific murine TCR S4-12. Subsequently, we further investigated the functional specificity of the novel murine TCR S4-12 after manipulating HLA-A2-positive PBLs to express the TCR (referred to $\mathrm{PBL}^{\mathrm{S4}-12}$ ). Levels of TCR S4-12 surface expression in the transduced PBLs were slightly different among donors, and elicited 25-35\% transduction efficiency compared to that in TCR-nontransduced $\mathrm{PBL}^{\text {mock }}$ (data not shown). Initially, the engineered $\mathrm{PBL}^{\mathrm{S4}-12}$ were stained using $\mathrm{LMP}_{166}$-loaded HLA-A2:Ig dimers, which revealed comparable results with HLA-A2 tetramer assay for the immunologic monitoring (Schneck, 2000; Woll et al, 2004). The representative data presented in Figure $2 \mathrm{~A}$ showed that $\mathrm{PBL}^{\mathrm{S4}-}$ 12 had high levels of LMP $1_{166^{-}}$specific TCR-transduced CD8 and CD4 T-cells ( $~ 9 \%$ per each), whereas no significant $\mathrm{LMP}_{166^{-}}$ specific staining was found in TCR S4-6-transduced PBLs (PBL ${ }^{\mathrm{S4}-}$ $\left.{ }^{6}\right)$, that was non-functional. Apparently, $\mathrm{PBL}^{\mathrm{S4-12}}$ were not stained with control peptide $\left(\mathrm{WT}_{126}\right)$-loaded HLA-A2:Ig dimers (Supplementary Figure S2). To assess the specific reactivity, HLA-A2-restricted LMP1-derived peptides were pulsed onto T2 cells, and co-cultured with the engineered $\mathrm{PBL}^{\mathrm{S} 4-12}$. Interestingly, $\mathrm{PBL}^{\mathrm{S} 4-12}$ were equipped to additionally recognise target cells pulsed with LMP $_{167}$ (LLVDLLWLL), which is one amino acid-shifted peptide from $L M P 1_{166}$, but not to other HLA-A2-restricted LMP1derived peptides including an irrelevant $\mathrm{WT}_{126}$ (Figure $2 \mathrm{~B}$ ). Moreover, PBL ${ }^{\mathrm{S} 4-12}$ were also stained with $\mathrm{LMP} 1_{167}$-loaded HLAA2:Ig dimers, but in low frequency compared to that of $L M P 1_{166^{-}}$ loaded HLA-A2:Ig dimers (Supplementary Figure S2). 
A

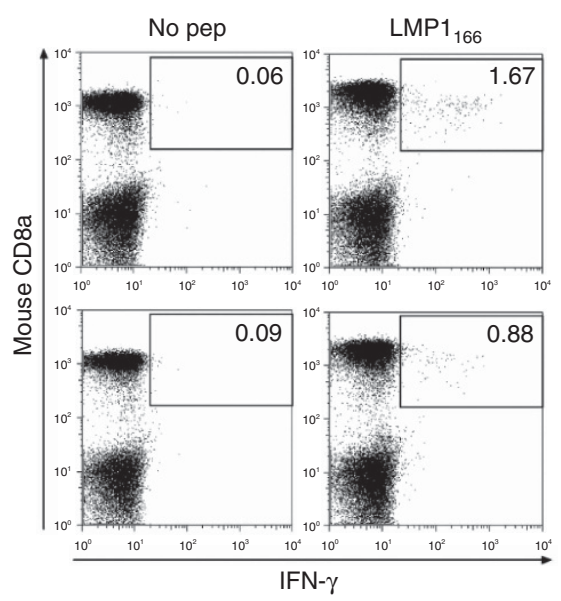

B

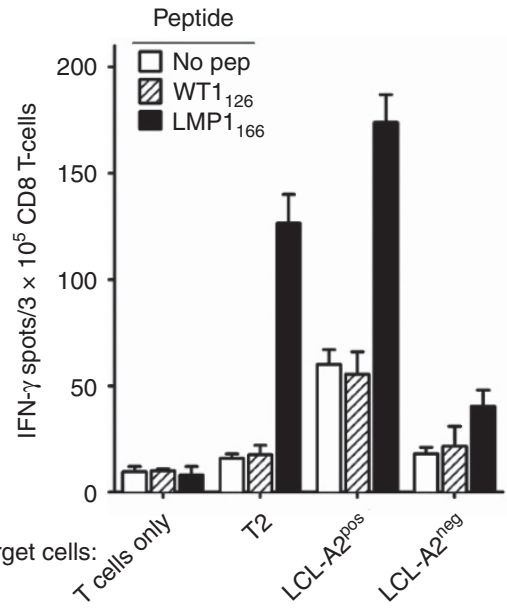

C
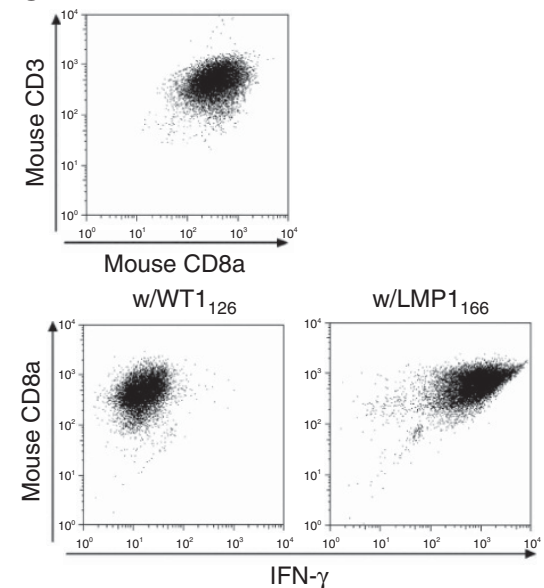

D
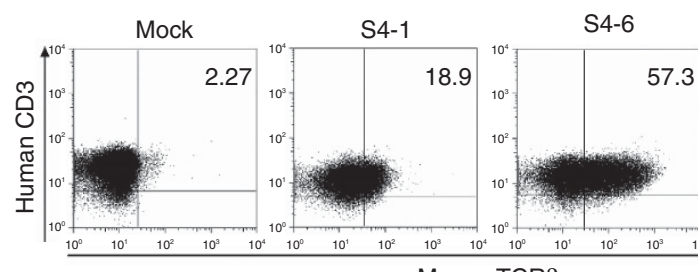

$4-6$

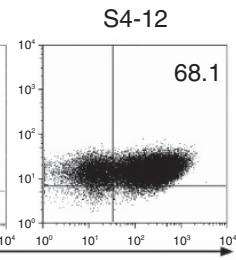

Mouse TCR $\beta$

PBL

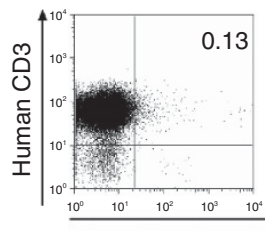

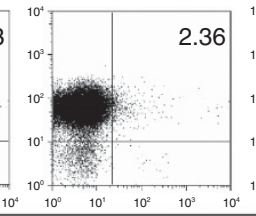

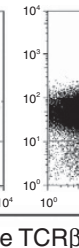

E

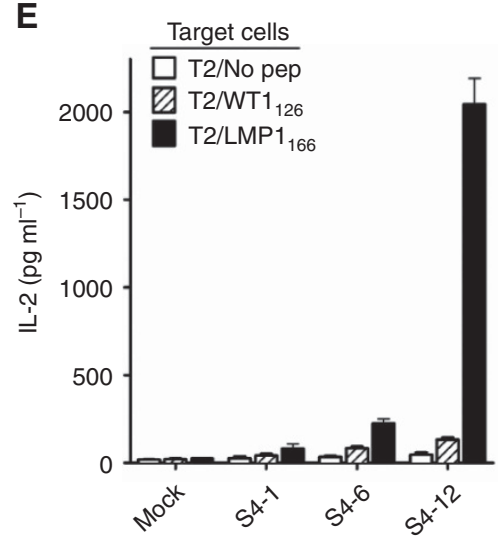

Figure 1. Isolation of murine TCR specific to LMP1 ${ }_{166}$ from CD8 T-cell clones. HLA-A2 Tg mice $(n=2)$ were immunised intravenously with $2 \times 10^{6}$ DCs loaded with LMP1 166 peptide for priming; 7 days later, the mice received a booster immunisation with TriVax. (A) Eight days after the booster, splenocytes were evaluated by intracellular IFN $\gamma$-staining after co-culturing with LMP1 166 , or without peptide (No pep). Numbers in each rectangular gate represent the percentage IFN $\gamma$-positive cells of all CD8 T-cells. (B) After 7 days of in vitro stimulation with LMP1 ${ }_{166}$-loaded DCs, antigen-induced IFN $\gamma$-secretion of CD8 T-cells was evaluated. T2, and HLA-A2-positive and HLA-A2-negative LCLs (LCL-A2 ${ }^{\text {pos }}$, LCL-A2 ${ }^{\text {neg }}$, respectively) that were pulsed with LMP1 166 or WT1 126 were used as APCs. Peptides only without APCs (T-cells only) and un-pulsed APCs (No pep) were used as controls. Results represent the average number of spots from triplicate wells with s.d. (bars) of the means. These experiments of (A) and (B) were repeated thrice with similar results. (C) A representative T-cell clone established by limiting dilution cloning was verified for CD8 expression (upper panel) and antigen-specificity by intracellular IFN $\gamma$-staining (lower panel). (D) The ex vivo-activated PBLs and Jurkat cells were transduced with the murine TCRs isolated from LMP1 ${ }_{166}$-specific T-cell clones (S4-1, S4-6, or S4-12). Surface expression in the transduced Jurkat cells (upper panel) and PBLs (lower panel) was examined on day-2 post-transduction. TCR-non-transduced cells (mock) were used as control. Numbers in each rectangular gate represent the percentage TCR-expressing cells of all human CD8 T-cells. (E) Antigen-specific functionality of isolated murine TCRs. The TCR-transduced PBLs were co-cultured with peptide-pulsed T2 cells for 2 days, and the culture supernatants were measured for IL-2 production using ELISA assay. Results represent the average amount of cytokines from two independent experiments with s.d. (bars). $L C L=$ lymphoblastoid cell lines; $L M P=$ latent membrane protein; $T C R=$ T-cell receptor.

Subsequently, peptides were serially diluted and pulsed onto T2 cells to evaluate the functional avidity of TCR S4-12. The engineered $\mathrm{PBL}^{\mathrm{S} 4-12}$ recognised $\mathrm{LMP}_{166}$-pulsed targets, and secreted IL-2 in a dose-dependent manner, at a concentration as low as $1 \mathrm{ng} \mathrm{ml}^{-1}$ of $\mathrm{LMP}_{166}$, whereas $\mathrm{PBL}^{\mathrm{S} 4-12}$ recognition against $\mathrm{LMP} 1_{167}$ was rapidly reduced by $100 \mathrm{ng} \mathrm{ml}^{-1}$ of $\mathrm{LMP} 1_{167}$ concentration, implying that LMP1 $1_{166}$ is a real or best antigenic epitope that can be recognised by TCR S4-12. Of note, the same was not observed for an irrelevant WT1 $1_{126}$ (Figure $2 \mathrm{C}$ ). As such, antigen-specific recognition and cytolytic activity of $\mathrm{PBL}^{\mathrm{S} 4-12}$ were validated compared with that of $\mathrm{PBL}^{\mathrm{S4}-6}$. As shown in Figure 2D and $\mathrm{E}$, functional activity of $\mathrm{PBL}^{\mathrm{S} 4-12}$ was evident, which displayed high levels of cytotoxicity towards LMP $1_{166}$-pulsed targets, whereas $\mathrm{PBL}^{\text {S4-6 }}$ did not respond to the target cells.
Murine TCR S4-12 can recognise endogenous processed HLAA2/LMP1 ${ }_{166}$ complexes. One potential concern with TCR S4-12 was whether $\mathrm{PBL}^{\mathrm{S4}-12}$ could directly recognise endogenous LMP1expressing target cells, rather than exogenously peptide-provided cells. DCs transfected with LMP1-RNA were applied as a target, which enabled presentation of HLA-A2/LMP $1_{166}$ complexes (pHLA-A2/LMP $1_{166}$ ) onto the cell surface by natural antigenprocessing pathways. As shown in Figure 3A, high level of $\mathrm{PBL}^{\mathrm{S4-12}}$ responses were observed against LMP1-RNA-electro-transferred DCs (DC/LMP1 $\left.1_{\mathrm{RNA}}\right)$, similar to those with $\mathrm{LMP} 1_{166}$-pulsed DCs $\left(\mathrm{DC} / \mathrm{LMP} 1_{166}\right)$ that showed the presence of saturated exogenous $\mathrm{LMP} 1_{166}$. In contrast, in vitro generated LMP1-specific cytotoxic T-cells that were stimulated with LMP1-RNA-transfected DCs from a same EBV-seropositive healthy donor did not respond to 
A

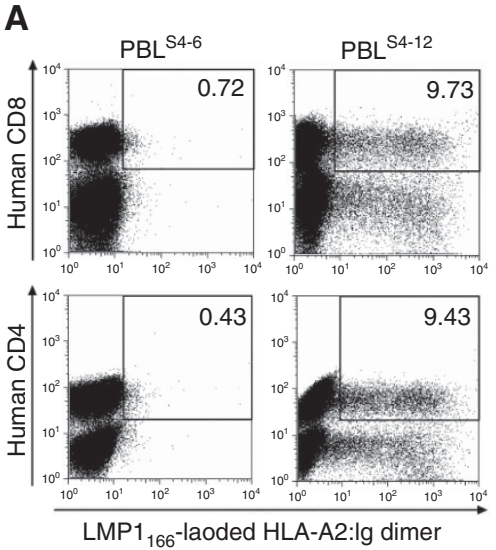

B

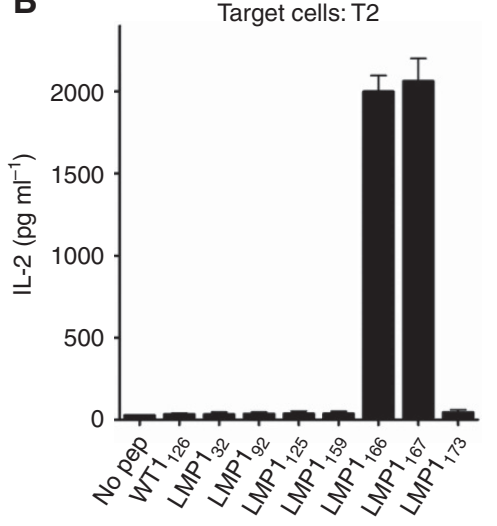

C

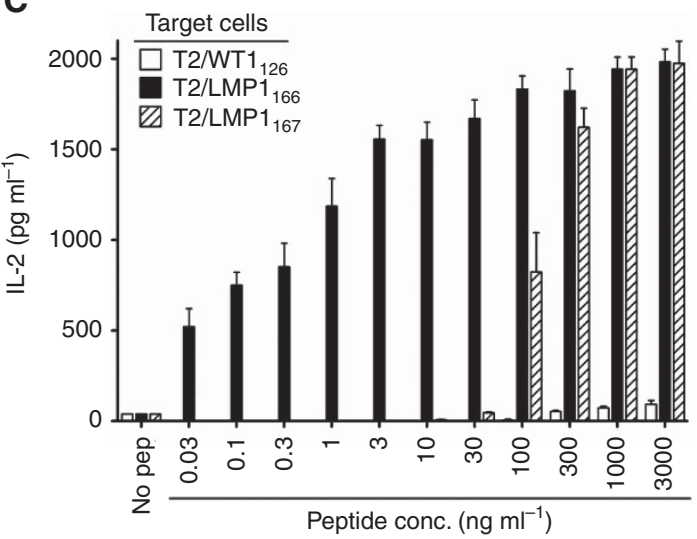

D

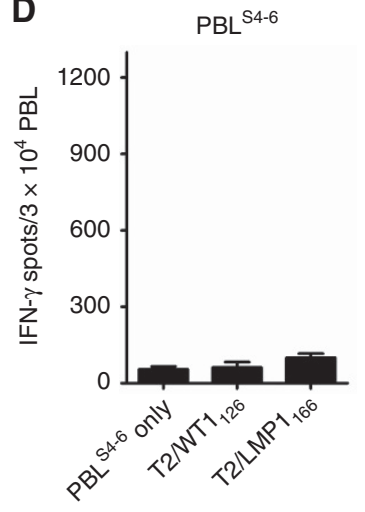

$\mathrm{PBL}^{\mathrm{S} 4-12}$

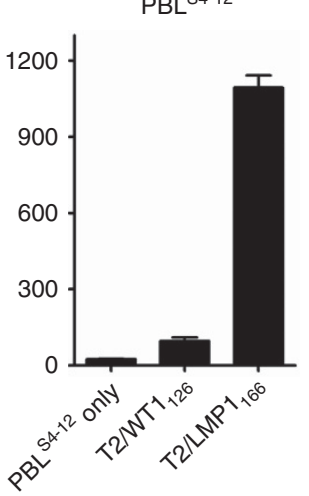

$\mathbf{E}$

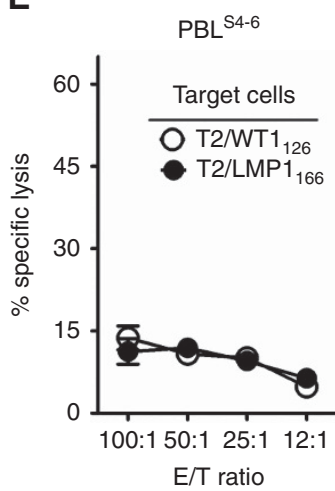

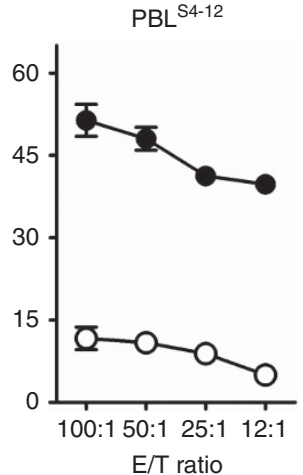

Figure 2. Evaluation of functional specificity of murine LMP1 ${ }_{166}$-specific TCR S4-12. (A) Murine TCR S4-6 and TCR S4-12-transduced PBLs (PBL ${ }^{\text {S4-6 }}$ and $\mathrm{PBL}^{\mathrm{S} 4-12}$, respectively) were stained with $\mathrm{LMP}_{166}$-loaded HLA-A2:Ig dimers on day 2 post-transduction and analysed by flow cytometry. Numbers in each rectangular gate represent the percentage peptide-dimer-positive cells of all human CD8 T-cells (upper panels) and CD4 T-cells (lower panels). These experiments were repeated two times with similar results. (B and C) Assessment of peptide specificity (B) and T-cell avidity (C) of TCR-transduced PBLs. PBL ${ }^{\mathrm{S} 4-12}$ were co-cultured with T2 cells that were pulsed with LMP1 166 , with irrelevant peptides as indicated, or without peptide (No pep) for 2 days. IL-2-ELISA assay was performed with the culture supernatants. Results represent the average amount of cytokines from triplicate wells with s.d. (bars) of the means. (D) Antigen-induced IFN $\gamma$-secretion of PBL ${ }^{\mathrm{S}-6}$ and $\mathrm{PBL}^{\mathrm{S}-12}$ was evaluated using EliSpot assay. Results represent the average number of spots from triplicate wells with s.d. (bars) of the means. (E) Cytolytic activity of engineered PBLs against LMP1 ${ }_{166}$-pulsed T2 cells was assessed by a ${ }^{51} \mathrm{Cr}$-release assay. Points represent the average values of cytotoxicity in different E:T ratio from triplicate wells with s.d. (bars) of the means. Engineered PBLs only and WT1 $1_{126}$-pulsed T2 cells were used as controls. These experiments were repeated twice with similar results. $\mathrm{LMP}=$ latent membrane protein; $\mathrm{PBL}=$ peripheral blood lymphocytes.

the DC/LMP1 $1_{166}$ targets (Supplementary Figure S3), indicating that the functional reactivities of $\mathrm{PBL}^{\mathrm{S}-12}$ are due to endowing TCR S4-12, not due to endogenous activities of EBV-seropositive donor. Nonetheless, exogenous LMP $1_{166}$-loaded LCL-A2 $2^{\text {pos }}$ were recognised, resulting in production of a high level of IL-2, and were efficiently lysed by $\mathrm{PBL}^{\mathrm{S} 4-12}$, whereas $\mathrm{PBL}^{\mathrm{S} 4-12}$ revealed relatively low responsiveness towards un-loaded and $\mathrm{WT}_{126}$-loaded LCL$\mathrm{A} 2^{\text {pos }}$ though LMP1 is known to be naturally expressed in LCLs (Figure $3 \mathrm{~B}$ and $\mathrm{C}$ ). However, the functional reactivities of $\mathrm{PBL}^{\mathrm{S} 4-12}$ towards LCL-A2 ${ }^{\text {pos }}$ target cells were significantly reduced by HLAA2 blocking (Supplementary Figure S4), implying that the $\mathrm{LMP} 1_{166}$-specific recognition of PBL ${ }^{\text {S4-12 }}$ is HLA-A2-restricted. Apparently, LCL-A2 ${ }^{\text {neg }}$ targets were not attacked while LMP1 $1_{166}$ were provided. To confirm the capability of TCR S4-12 to recognise endogenously processed pHLA-A2/LMP $1_{166}$ on target cells, we established K562-derived stable transfectants that expressed HLA-A2 alone (K-A2) and/or together with LMP1 (K$\mathrm{A} 2_{\mathrm{LMP} 1}$ ). After selection, LMP1 expression was examined in K-A2 and $\mathrm{K}-\mathrm{A} 2_{\mathrm{LMP} 1}$ transfectants as well as LCL, results showed much lower level of LMP1 expression in LCL than K-A2 LMP1 cells (data not shown). Likewise, $\mathrm{PBL}^{\mathrm{S} 4-12}$ were effective in recognising $\mathrm{K}-\mathrm{A} 2_{\mathrm{LMP} 1}$ pulsed either with or without $\mathrm{LMP}_{166}$ (Figure $4 \mathrm{~A}$ ), whereas TCR-non-transduced $\mathrm{PBL}^{\text {mock }}$ and TCR S4-6-transduced $\mathrm{PBL}^{\mathrm{S4}-6}$ did not respond to the target cells (Supplementary Figure S5). In accordance, higher cytolytic activity of $\mathrm{PBL}^{\mathrm{S4}-12}$ was observed against K-A2 2 MP1 as compared to that with $\mathrm{PBL}^{\mathrm{S} 4-6}$ (Figure $4 \mathrm{~B}$ ). These data indicate that $\mathrm{K}-\mathrm{A} 2_{\mathrm{LMP} 1}$ presents $\mathrm{pHLA}$ $\mathrm{A} 2 / \mathrm{LMP} 1_{166}$ on the surface through intrinsic LMP1-processing machinery.

We examined the composition of $\mathrm{PBL}^{\mathrm{S} 4-12}$ to clarify which subsets of T-cells have effector functions. As shown in Figure 4C, $\mathrm{PBL}^{\mathrm{S} 4-12}$ were mainly composed of CD8 T-cells (CD8 $\mathrm{T}^{\mathrm{s} 4-12}$; $\sim 25 \%$ ) but CD4 T-cells (CD4 $\mathrm{T}^{\mathrm{S4-12}}$; $\sim 10 \%$ ) were also present, which are crucial for the persistence of transferred CD8 T-cells and long-term immunologic memory T-cell responses. Notably, purified CD4 $\mathrm{T}^{\mathrm{S4}-12}$ exhibited high levels of IL-2 production similar to those with that of purified CD8 $\mathrm{T}^{\mathrm{S} 4-12}$ in response to LMP1 $1_{166}$-loaded targets including K-A2 $2_{\text {LMP1 }}$ (Figure $4 \mathrm{D}$ ), as specific HLA-A2:Ig dimer bindings were observed in CD4 T-cells as well as CD8 T-cells (Figure 2A). Likewise, we manipulated cordblood lymphocytes with TCR S4-12, which can also be used as a potential source of effector cells since the differentiation status of TCR-engineered T-cells is a factor influencing long-term in vivo persistence of infused cells. The engineered cord-blood 

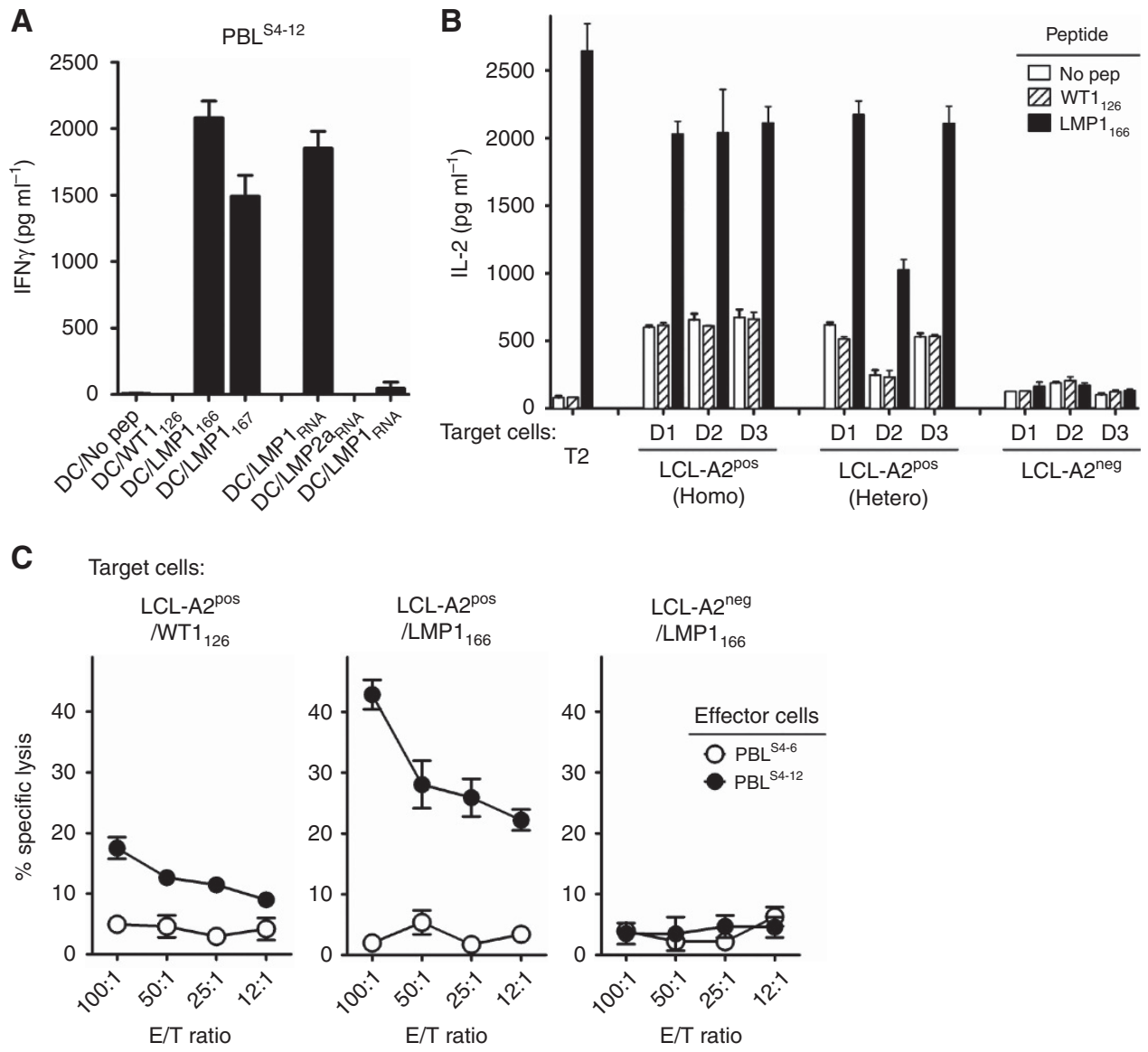

Figure 3. Antitumour activity of $\mathrm{PBL}^{\mathrm{S4-12}}$. (A) $\mathrm{PBL}^{\mathrm{S} 4-12}$ were capable of recognising LMP1-expressing DCs. PBL ${ }^{\mathrm{S} 4-12}$ were co-cultured with peptidepulsed, or RNA-electro-transferred DCs as indicated for 2 days. DCs without peptide (No pep), irrelevant WT1 126, LMP2a- and WT1-RNA were used for controls. IFN $\gamma$-ELISA assay was performed with the culture supernatants. Results represent the average amount of cytokines from triplicate wells with s.d. (bars) of the means. (B and C) The functional specificity (B) and cytolytic activity (C) of PBL ${ }^{\text {S4-12 }}$ were evaluated towards HLA-A2positive or HLA-A2-negative LCLs (LCL-A2 ${ }^{\text {pos }}$ and LCL-A2 ${ }^{\text {neg }}$, respectively), which were pulsed with LMP1 166, WT1 126 , or without peptide (No pep). (B) LCL-A2 ${ }^{\text {pos }}$ were established from HLA-A2 homozygous (Homo) and/or HLA-A2 heterozygous (Hetero) donors, and three different donorderived LCLs were used (D1, D2, and D3). T2 cells were also included. IL-2-ELISA assay was performed with the culture supernatants. Results represent the average amount of cytokines from two independent experiments with s.d. (bars). (C) PBL ${ }^{\mathrm{S}-6}$ were used as control. Points represent the average values of cytotoxicity in different E:T ratio from triplicate wells with s.d. (bars) of the means. These experiments were repeated twice with similar results. $\mathrm{LCL}=$ lymphoblastoid cell lines; $\mathrm{LMP}=$ latent membrane protein; $\mathrm{PBL}=$ peripheral blood lymphocytes.

lymphocytes exhibited high level of IL-2 secretion similar to that of PBLs towards LMP1 $1_{166}$-loaded and/or LMP1-expressing K-A2 2 LP1 and LCL target cells (Supplementary Figure S6). Overall, these results indicate that TCR S4-12 has high affinity for the recognition of the endogenously processed $\mathrm{pHLA}-\mathrm{A} 2 / \mathrm{LMP} 1_{166}$ target, and that functionality of TCR S4-12 is dependent on the degree of LMP1 expression in target cells.

In vivo therapeutic antitumour efficacy of $\mathrm{PBL}^{\mathrm{S4}-12}$. Next, we assessed whether adoptive transfer of $\mathrm{PBL}^{\mathrm{S4}-12}$ would offer a therapeutic benefit in vivo using a xenogeneic model, which was systemically engrafted with luciferase-expressing $\mathrm{K}-\mathrm{A} 2_{\mathrm{LMP} 1}(\mathrm{~K}-$ $\mathrm{A} 2_{\mathrm{LMP} 1 / \mathrm{LUC}}$ ), and a bioluminescent imaging technique to monitor tumour growth. Mice that were intravenously engrafted with $\mathrm{K}-\mathrm{A} 2_{\mathrm{LMP} 1 / \mathrm{LUC}}$ underwent adoptive infusion with $\mathrm{PBL}^{\text {mock }}, \mathrm{PBL}^{\mathrm{S} 4-6}$, or $\mathrm{PBL}^{\mathrm{S} 4-12}$ on day 7 (Figure $5 \mathrm{~A}$ ). Mice treated with $\mathrm{PBL}^{\mathrm{S4-12}}$ had a reduced tumour progression as compared to those with $\mathrm{PBL}^{\text {mock }}$ or $\mathrm{PBL}^{\mathrm{S} 4-6}$, drawing significantly lower bioluminescent signal by day 42 (Figure $5 \mathrm{~B}$ and $\mathrm{C}$ ). As such, the adoptive transfer of $\mathrm{PBL}^{\mathrm{S} 4-12}$ revealed significantly increased median survival of the mice by more than $\geqslant 2$ weeks (Figure 5D), and the measurement of genetically modified (mouse TCR and human CD45 double- positive) cell numbers in blood at day 20 (2 weeks after cell infusion) showed sustained high numbers of $\mathrm{PBL}^{\mathrm{S} 4-12}$, correlated with the observed improved antitumour effects (Figure 5E), indicating that TCR-transduced $\mathrm{PBL}^{\mathrm{S} 4-12}$ have potential for substantial long-term engraftment in vivo after adoptive transfer.

Ex vivo expansion of CD8 $\mathrm{T}^{\mathrm{S4-12}}$ and $\mathrm{PBL}^{\mathrm{S4-12}}$. Additionally, we investigated optimal conditions for ex vivo expansion conditions to obtain sufficiently high numbers of TCR-transduced cells for clinical applications, which is a prerequisite for the success of adoptive immunotherapy. For these experiments, we established K-A2-based APCs expressing co-stimulatory molecules CD80 and 4-1BBL (K-A2 $80 / 4-1 \mathrm{BBL})$, which can increase the survival of activated T-cells. Subsequently, $\mathrm{PBL}^{\mathrm{S4-12}}$ and $\mathrm{CD} 8 \mathrm{~T}^{\mathrm{S} 4-12}$ were expanded with $\mathrm{LMP}_{166^{-}}$or $\mathrm{WT}_{126^{-}}$-loaded $\mathrm{K}-\mathrm{A} 2_{80 / 4-1 \mathrm{BBL}}$ and compared with conventional anti-CD3/CD28-coated beads (Figure 6A). In this setup, stimulation with $\mathrm{LMP} 1_{166}$-loaded $\mathrm{K}-\mathrm{A} 2_{80 / 4-1 \mathrm{BBL}}$ revealed expansion of distinct clear homogeneous populations of CD8 $\mathrm{T}^{\mathrm{S} 4-12}$ (Figure $6 \mathrm{~B}$ ), which resulted in higher absolute numbers of CD8 T-cells compared to those with antiCD3/CD28-coated beads ( $\sim 400$-fold versus $\sim 200$-fold increase in $\mathrm{PBL}^{\mathrm{S4-12}}$ expansion); no significant $\mathrm{T}$-cell expansion was found 
A

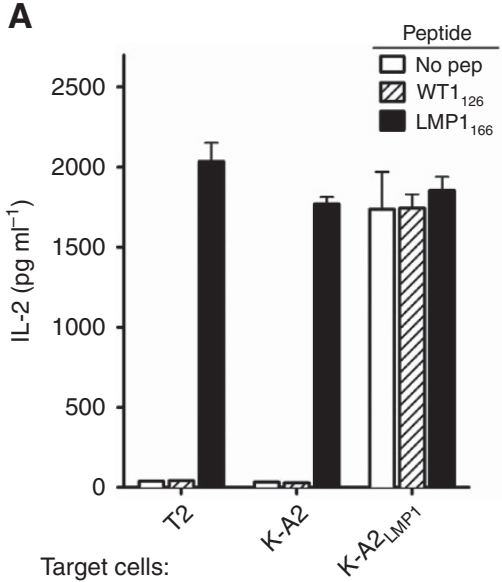

C

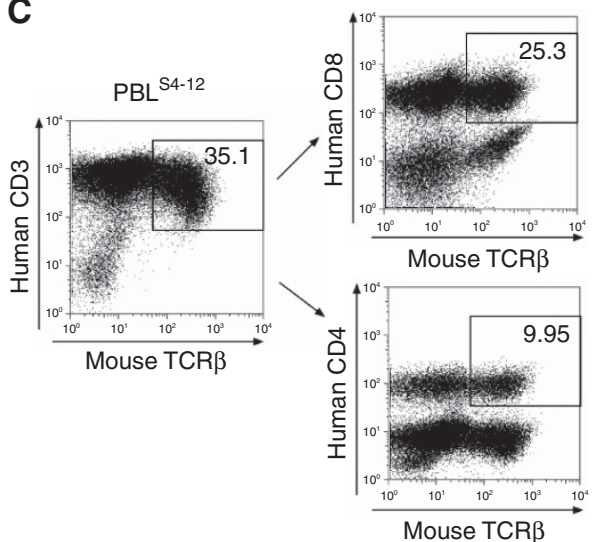

B

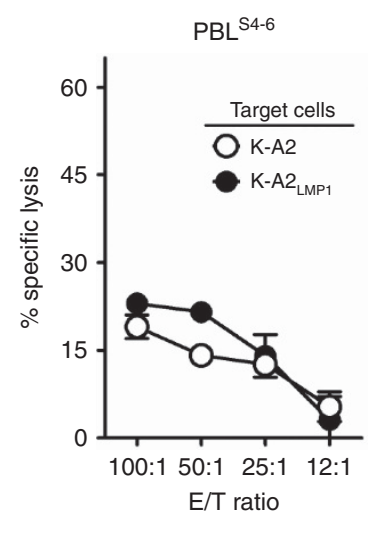

D

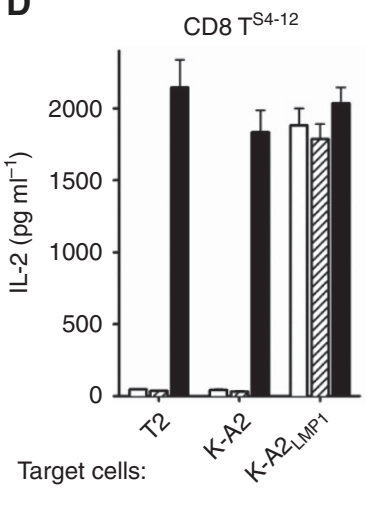

$\mathrm{PBL}^{\mathrm{S} 4-12}$

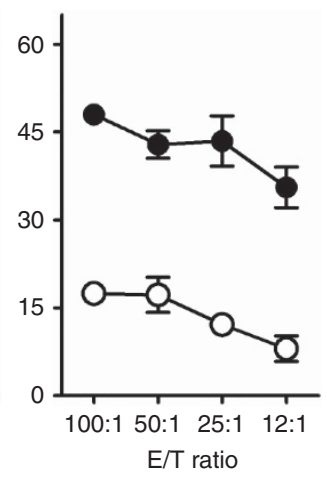

Figure 4. $\mathrm{PBL}{ }^{\mathrm{S} 4-12}$ recognise endogenously processed LMP1 ${ }_{166} / \mathrm{HLA}-\mathrm{A} 2$ complexes on tumour cells. (A and $\left.\mathrm{B}\right) \mathrm{PBL}{ }^{\mathrm{S}-12}$ recognise $\mathrm{HLA}-\mathrm{A} 2$ and LMP1 co-expressing K562 cells (K-A2 LMP1). K562 expressing HLA-A2 alone (K-A2) and T2 cells without peptide (No pep) or with peptides (WT1 126 and LMP1 166) were also included. IL-2-ELISA assay (A) and ${ }^{51} \mathrm{Cr}$-release assay (B) were performed as in Figure 3 including K-A2 and K-A2 LMP1 cells. (B) Effector $\mathrm{PBL}^{\mathrm{S} 4-6}$ were used as a control. Points represent the average values of cytotoxicity in different E:T ratio from triplicate wells with s.d. (bars) of the means. (C and D) Functional specificity of CD8 $T^{\text {S4-12 }}$ and CD4 T $\mathrm{T}^{\mathrm{S4}-12}$. (C) Expression of TCR S4-12 in CD8 and CD4 T-cells was examined by flow cytometry. Numbers in each rectangular gate represent the percentage TCR S4-12-positive cells of all human T-cell subsets. (D) Antigenic specificity of purified CD8 $T^{S 4-12}$ and CD4 $T^{S 4-12}$ was evaluated as described above. (A and D) Results represent the average amount of cytokines from two independent experiments with s.d. (bars). These experiments were repeated twice with similar results. $L C L=$ lymphoblastoid cell lines; $\mathrm{LMP}=$ latent membrane protein; $\mathrm{PBL}=$ peripheral blood lymphocytes; $\mathrm{TCR}=\mathrm{T}$-cell receptor.

with $\mathrm{WT} 1_{126}$-loaded $\mathrm{K}-\mathrm{A} 2_{80 / 4-1 \mathrm{BBL}}$ (Figure $6 \mathrm{C}$ ). The ex vivo expanded CD8 T-cells under all conditions for 3 weeks were mainly composed of effector-memory-like $\mathrm{CD}_{45 \mathrm{RO}}{ }^{+} / \mathrm{CD} 2 \mathrm{~L}^{-}$ phenotypes (Supplementary Figure S7). Moreover, antigen specificity of ex vivo expanded TCR-engineered cells was maintained during 28-day culture (Figure 6D), indicating that our artificial APCs can promote engineered cell proliferation with a homogeneously enriched population that maintained intact antigenic functional specificity.

\section{DISCUSSION}

EBV-specific T-cells have been successfully applied to restore EBVspecific immunity in patients with EBV-latency-III malignancies, whereas they have been in limited use for the treatment of EBVlatency-II malignancies, such as NK/T-cell lymphoma. Thus, extension of current adoptive immunotherapies toward EBVlatency-II malignancies demands more efficient immunotherapeutic strategies to generate sufficient numbers of $\mathrm{T}$-cells specific to EBV-latency-II antigens, such as LMP1. Consequently, we and other have developed ex vivo expansion protocols capable of generating LMP1-specific T-cells using LMP1-expressing APCs that were transduced with mRNA (Demachi-Okamura et al, 2006; Cho et al, 2015b) or recombinant viruses (Gottschalk et al, 2003). However, in the clinical realm, there are significant drawbacks for reactivation of LMP1-specific T-cells because LMP1 is toxic when expressed at high levels (Hammerschmidt et al, 1989), and the precursor frequency of LMP1-specific T-cells is very low in healthy EBV-seropositive individuals (Khanna et al, 1998). Here, we explored the functional availability of genetically modified T-cells to endow antigenic specificity towards LMP1, which is a recent approach to rapidly manufacture large numbers of potent tumourreactive effector cells. To our knowledge, this is the first report showing that T-cells engineered with LMP1-specific TCR enable them to recognise and elicit specific cytotoxicity towards LMP1expressing tumour cells in vitro and in a xenogeneic allograft model in vivo.

Over a considerable period of time, adoptive transfer of ex vivoengineered T-cells has been successful; particularly, anti-CD19CAR-T-cells have demonstrated objective clinical responses towards B-cell malignancies, including complete remissions (Porter et al, 2011; Lee et al, 2015). Despite spreading and bypassing the HLA dependency, the CAR-T-cell-based approach requires surface expression of antigens and risks development of 
A
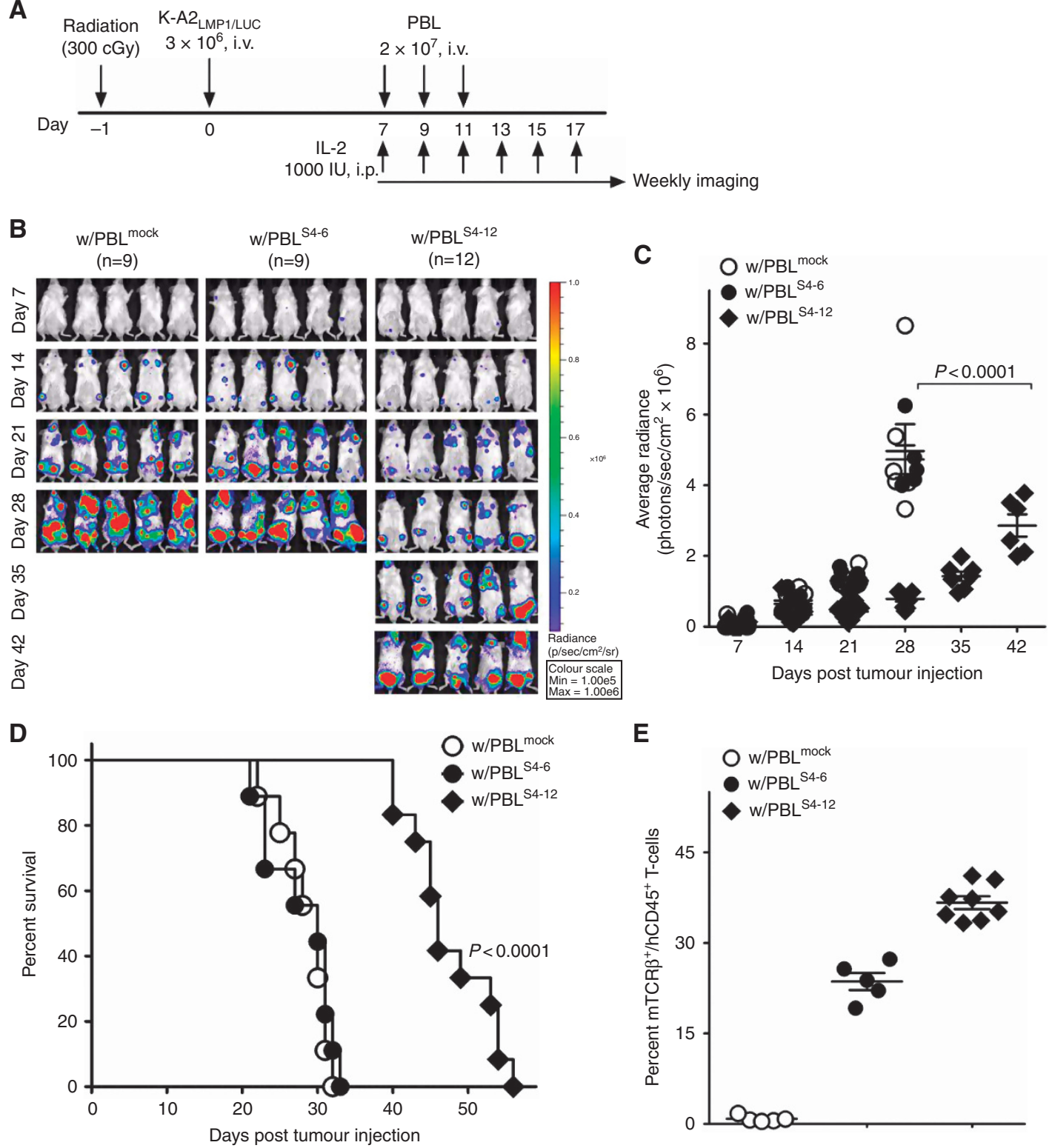

Figure 5. Adoptive transfer of $\mathrm{PBL}^{\text {S4-12 }}$ prolongs survival of mice with LMP1-expressing tumours. (A) Schematic experimental plan. Sublethally irradiated ( 300 cGy) NSG mice intravenously received K-A2LMP1/LUC $\left(3 \times 10^{6}\right.$ cells per mouse) on day 0 . Engineered PBLs $\left(2 \times 10^{7}\right.$ cells per mouse) were infused thrice and IL-2 was administrated six times with a 2-day interval, followed by weekly bioluminescence imaging. (B) Time course of in vivo bioluminescence imaging in representative individual mice treated with $\mathrm{PBL}^{\mathrm{S4}-6}(n=9)$ or $\mathrm{PBL}^{\mathrm{S} 4-12}(n=12)$. A group treated with $\mathrm{PBL}^{\text {mock }}$ $(n=9)$ was included as control. Images were adjusted to the same pseudo colour scale to show relative bioluminescence changes over time. (C) Tumour growth was monitored by in vivo bioluminescence imaging. Average radiance per mouse in $B$ was shown. Points represent the average values photons in mouse with s.d. (bars) of the means. P-values were calculated using two-way ANOVA test compared to the PBL ${ }^{\text {S4-6 }}$-infused group. (D) Kaplan-Mayer survival curves for all groups of mice. P-values were determined by log-rank tests compared to the PBL ${ }^{\text {S4-6 }}$-infused group. (E) Frequency of PBLs expressing murine TCR was evaluated on day 20 with blood samples from mice in (D). Points represent the percentage for each group of mice with s.d. (bars) of the means. These experiments were repeated twice with similar results. LMP =latent membrane protein; $\mathrm{LUC}=$ luciferase; $\mathrm{PBL}=$ peripheral blood lymphocytes; $\mathrm{TCR}=\mathrm{T}$-cell receptor.

tumour escape variants (Grupp et al, 2013; Anurathapan et al, 2014). In this respect, though it requires selection of patients with appropriate HLA alleles, TCR-engineered T-cells provide an effective therapeutic option for patients with CAR-T-induced tumour variants due to their high sensitivity for naturally processed antigenic peptides-HLA complexes (Corse et al, 2011; Caruso et al, 2015). Recent clinical trials using T-cells engineered with NY-ESO-1-specific TCR have shown objective responses in patients with melanoma, synovial cell carcinoma, and multiple myeloma (Robbins et al, 2011; Rapoport et al, 2015). In similar strategies to develop EBV-specific TCR-based therapies, numerous reports have shown objective EBV-specificities and in vivo therapeutic efficacies of genetically modified T-cells with isolated TCRs specific to HLA-A2- or HLA-A11-restricted LMP2 epitopes (Frumento et al, 2013; Xue et al, 2013; Zheng et al, 2015).

Selection of target T-cell epitopes is critical for the development of effective TCR-based T-cell immunotherapy. Here, we focus on an HLA-A2-restricted $\mathrm{LMP}_{166}$ epitope, which may be a subdominant epitope from LMP1, although it could be rather dominant in some situations. Khanna and colleagues have reported HLA-A2-restricted LMP1 epitopes (Khanna et al, 1998), and demonstrated that immunisation with recombinant viruses 


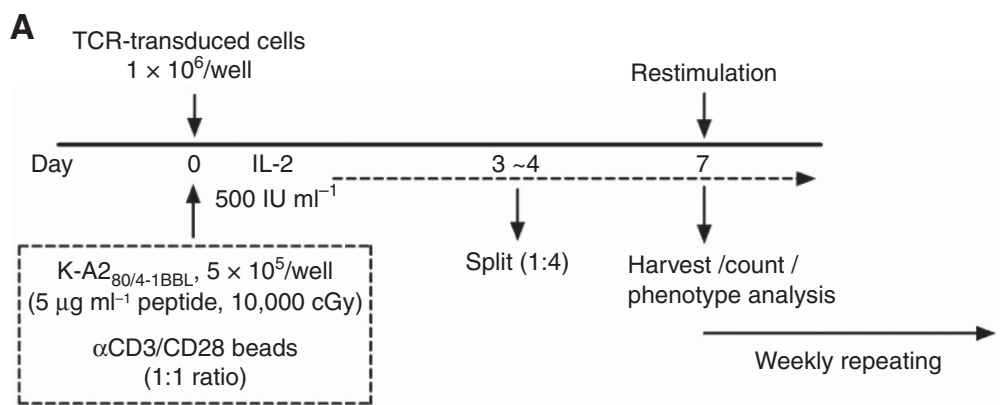

B
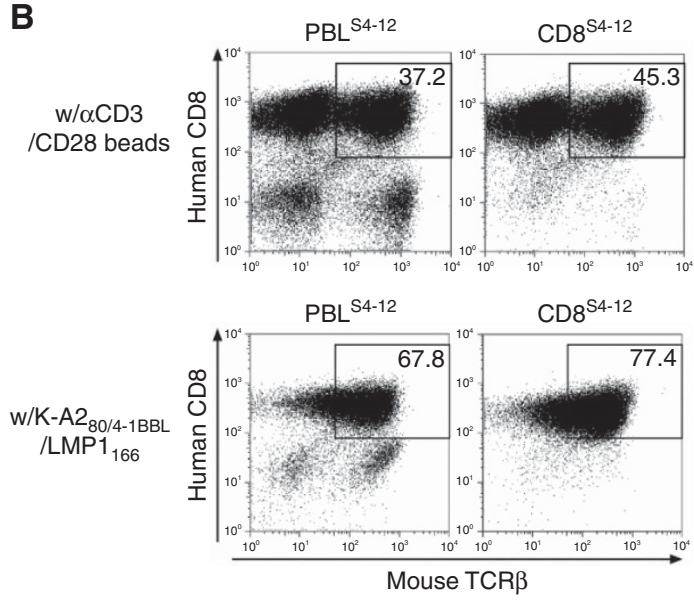

D

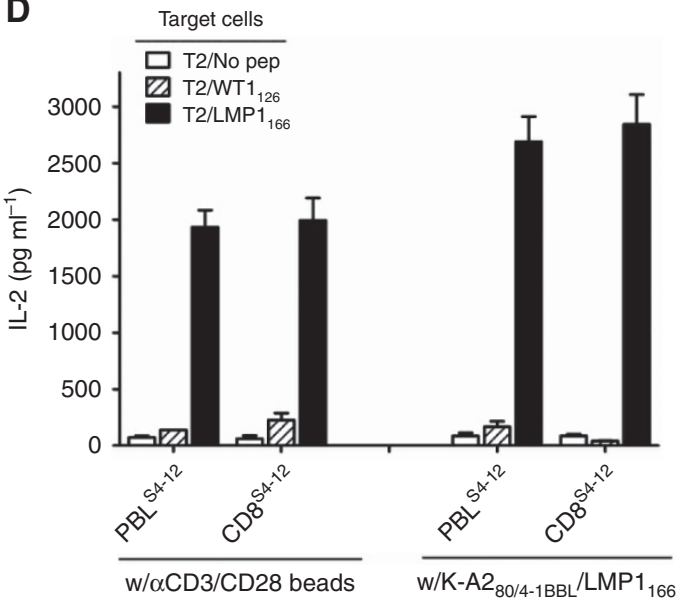

C

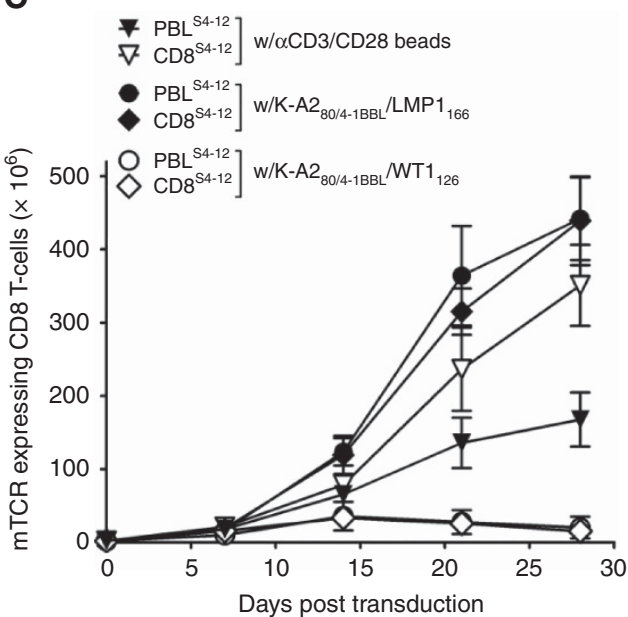

Figure 6. Ex vivo expansion of the engineered CD8 T-cells and PBLs. (A) Schematic experimental plan. CD8 $\mathrm{T}^{\mathrm{S4}-12}$ and PBL $\mathrm{S}^{\mathrm{S}-12}$ were co-cultured with artificial K-A280/4-18BL cells, which were pulsed with LMP1 166 or WT1 126, compared to anti-CD3/CD28-coated beads (1:1 ratio) with $500 \mathrm{IU} \mathrm{ml}^{-1} \mathrm{IL}-2$. (B) A representative analysis of murine TCR in ex vivo expanded CD8 $\mathrm{T}^{54-12}$ and PBL ${ }^{54-12}$ stimulated with either anti-CD3/CD28-

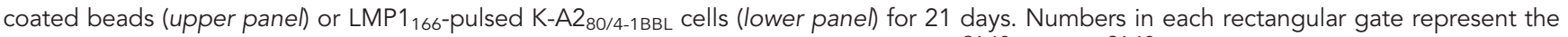
percentage TCR S4-12-positive cells of all human CD8 T-cells. (C) Proliferation of CD8 $\mathrm{T}^{\mathrm{S4}-12}$ and $\mathrm{PBL}^{\mathrm{S4-12}}$ in response to various conditions. Total numbers of murine TCR-expressing CD8 T-cells was calculated. Points, mean numbers of CD8 T-cell expansion over time; bars, s.d. Data are sum of single experiment on five donors. (D) Functional specificity of ex vivo expanded CD8 $\mathrm{T}^{\mathrm{S4}-12}$ and $\mathrm{PBL} \mathrm{L}^{\mathrm{S4}-12}$ was evaluated as in Figure 3B. Results represent the average amount of cytokines from two independent experiments with s.d. (bars). These experiments were repeated thrice with similar results. $\mathrm{LCL}=$ lymphoblastoid cell lines; $\mathrm{LMP}=$ latent membrane protein; $\mathrm{PBL}=$ peripheral blood lymphocytes; $\mathrm{TCR}=\mathrm{T}$-cell receptor.

encoding multiple LMP1 epitopes (including LMP1 $1_{166}$ ) induced potent T-cell responses against LMP1-expressing tumours (Duraiswamy et al, 2003). Although potential immune defects against EBV infection are not fully understood, it is generally accepted that persistent viral infection induces inefficient anergic T-cells eliciting immune tolerance and therefore fails to eliminate viral-infected cells in patients. Moreover, clonal T-cell anergy and the related adaptive tolerance is likely to remove high avidity
T-cells specific for immune-dominant epitopes to a higher extent than those for subdominant epitopes, and subdominant T-cell epitopes are detected after immunisation with vaccines lacking immunodominant peptides (Rodriguez et al, 2001). Thus, isolation of TCRs specific for subdominant T-cell epitopes may be effective to manipulate genetic engineering of T-cell immunity. In view of this, our results show that T-cells engineered with $\mathrm{LMP} 1_{166^{-}}$-TCR could be specifically activated using a low concentration of 
peptides (Figure 2C), and these cells efficiently recognised peptideloaded LCL-A2 ${ }^{\text {pos }}$ and LMP1-transfected tumour cells (Figure 4). These results imply that LMP1 $1_{166}$-TCR could have high avidity for antigen recognition and could be activated after a strong TCR stimulus capable of initiating a signal transduction cascade. Nonetheless, engineered cells exhibited relatively low responsiveness towards un-treated LCL-A2 ${ }^{\text {pos }}$ targets (Figure 3), in line with previous reports that demonstrate no or low responsiveness of T-cells transduced with TCR specific to EBV and HIV antigens towards native antigen-positive cells (Orentas et al, 2001; Schaft et al, 2006) and virus-infected targets (Ueno et al, 2004). Particularly, CD28-CD3 $\xi$ domain-conjugate TCR specific to EBV antigen enhanced cytokine-secretion responses towards antigenpositive targets (Schaft et al, 2006), suggesting that properties of isolated TCRs such as signalling capacity may be responsible for TCR reactivity.

The clinical success of TCR-based therapies notwithstanding, potential concerns have been raised over the use of isolated TCR, because the pairing of transduced and endogenous TCR chains in TCR-gene-modified T-cells may induce unknown and possibly hazardous self-reactive side effects (Bendle et al, 2010; van Loenen et al, 2010). To this end, several groups have explored to improve transduced TCR pairing. Murine TCRs provide an alternative source for high-affinity TCRs because the murine TCR repertoire is non-tolerant to many human antigens (Chinnasamy et al, 2011; Rosati et al, 2014). Rosenberg and colleagues have reported that clinical trials using murine TCR-transduced cells demonstrated substantial antitumour responses (Johnson et al, 2009; Parkhurst et al, 2011; Morgan et al, 2013) and some patients with murine TCRs developed antibodies against TCR-variable regions with no effect on the clinical outcome (Davis et al, 2010). Furthermore, murine-human hybrid-TCRs produced by substituting the human constant region with the murine constant region showed a higher expression of the receptor, increased cytokine secretion, and enhanced antitumour activity mediated by improved TCR pairing and CD3 stability (Cohen et al, 2006; Goff et al, 2010). Overall, these studies support that the isolated murine LMP $1_{166}$-TCR could be applied in clinical trials with or without further genetic modification to treat EBV latency-II malignancies.

The clinical efficacy of infused T-cells correlates with their ability to sufficiently persist in vivo to exhibit substantial antitumour responses. Several studies have demonstrated that in vivo persistence and measurable antitumour immunity depends on the differential status of effector T-cells (Morgan et al, 2006; Hinrichs et al, 2009; Rosenberg et al, 2011). In view of this, a recent study reported that cord-blood T-cells can be used as a potential source for TCR-gene transfer because most of these cells belong to naïve T-cell subsets (Frumento et al, 2013). We also observed that LMP1 $1_{166}$-TCR-transduced cord-blood T-cells exhibit levels of cytokine secretion similar to that of peripheral CD8 T-cells towards LMP1-expressing targets (Supplementary Figure S6). Likewise, CD4 T-cells also play a crucial role in the persistence of transferred CD8 T-cells and generation of long-term memory T-cells, and significantly contribute to tumour prevention in vivo (Mitsuyasu et al, 2000). A previous report showed that TCRengineered CD4 T-cells can confer functional specificity and subsequent antitumour immunity capable of preventing the tumour growth in vivo (Xue et al, 2013). Our results also showed the generation of TCR-engineered CD4 T-cells capable of recognising LMP1-expressing tumours (Figure 4), suggesting that pHLA-A2/LMP1 $1_{166}$-restricted CD4 T-cells could improve proliferation and memory development of adoptively transferred CD8 T-cells. The success of T-cell-based immunotherapy usually requires large numbers of cells $\left(\geqslant 10^{9}\right)$ with intact effector functions. Nevertheless, long-term ex vivo cultured T-cells possess terminally differentiated properties, demonstrating low persistence in vivo. Numerous groups have developed ex vivo T-cell culturing protocols with anti-CD3/CD28-coated activator beads (Rasmussen et al, 2010; Brimnes et al, 2012). Particularly, Butler and colleagues have reported anti-CD3 antibody-expressing artificial APC-based system for in vitro expansion of CD8 T-cells under autologous assistance of CD4 T-cell (Butler et al, 2012). We have also developed ex vivo engineered $\mathrm{T}$-cell expansion regimes with artificial APCs expressing HLA molecules and co-stimulatory CD80 and 4-1BBL (Figure 6). Notably, the exponentially expanded TCR-transduced T-cells could still maintain their functional specificity with a homogeneously enriched CD8 T-cell population.

In summary, we describe a novel HLA-A2-restricted TCR that specifically recognises $L M P 1_{166}$ epitope and provide the first evidence that $\mathrm{LMP} 1_{166}$-TCR engineered T-cells allow efficient recognition to display potent cytotoxicity towards engineered LMP1-overexpressing tumour cells in vitro and in vivo. Additional studies for optimising the TCR avidity that affect the specificity of TCR-transferred T-cells could facilitate clinical applications in the treatment of EBV-associated diseases, including EBV latency-II malignancies.

\section{ACKNOWLEDGEMENTS}

This study was supported by a grant of the Korean Health Technology R\&D Project, Ministry of Health \& Welfare, Republic of Korea (HI12C0718), and Basic Science Research Program through the National Research Foundation of Korea (NRF) funded by the Ministry of Science, ICT and future Planning (NRF2015R1A2A2A01004309).

\section{CONFLICT OF INTEREST}

The authors declare no conflict of interest.

\section{REFERENCES}

Anurathapan U, Chan RC, Hindi HF, Mucharla R, Bajgain P, Hayes BC, Fisher WE, Heslop HE, Rooney CM, Brenner MK, Leen AM, Vera JF (2014) Kinetics of tumor destruction by chimeric antigen receptormodified T-cells. Mol Ther 22(3): 623-633.

Bendle GM, Linnemann C, Hooijkaas AI, Bies L, de Witte MA, Jorritsma A, Kaiser AD, Pouw N, Debets R, Kieback E, Uckert W, Song JY, Haanen JB, Schumacher TN (2010) Lethal graft-versus-host disease in mouse models of T-cell receptor gene therapy. Nat Med 16(5): 565-5701p following 570. Bollard CM, Gottschalk S, Torrano V, Diouf O, Ku S, Hazrat Y, Carrum G, Ramos C, Fayad L, Shpall EJ, Pro B, Liu H, Wu MF, Lee D, Sheehan AM, $\mathrm{Zu}$ Y, Gee AP, Brenner MK, Heslop HE, Rooney CM (2014) Sustained complete responses in patients with lymphoma receiving autologous cytotoxic T lymphocytes targeting Epstein-Barr virus latent membrane proteins. J Clin Oncol 32(8): 798-808.

Brimnes MK, Gang AO, Donia M, Thor Straten P, Svane IM, Hadrup SR (2012) Generation of autologous tumor-specific T-cells for adoptive transfer based on vaccination, in vitro restimulation and CD3/CD28 dynabead-induced T-cell expansion. Cancer Immunol Immunother 61(8): 1221-1231.

Butler MO, Imataki O, Yamashita Y, Tanaka M, Ansen S, Berezovskaya A, Metzler G, Milstein MI, Mooney MM, Murray AP, Mano H, Nadler LM, Hirano N (2012) Ex vivo expansion of human CD8 + T-cells using autologous CD4 + T-cell help. PLoS One 7(1): e30229.

Caruso HG, Hurton LV, Najjar A, Rushworth D, Ang S, Olivares S, Mi T, Switzer K, Singh H, Huls H, Lee DA, Heimberger AB, Champlin RE, Cooper LJ (2015) Tuning sensitivity of CAR to EGFR density limits recognition of normal tissue while maintaining potent antitumor activity. Cancer Res 75(17): 3505-3518.

Chinnasamy N, Wargo JA, Yu Z, Rao M, Frankel TL, Riley JP, Hong JJ, Parkhurst MR, Feldman SA, Schrump DS, Restifo NP, Robbins PF, Rosenberg SA, Morgan RA (2011) A TCR targeting the HLA-A*0201- 
restricted epitope of MAGE-A3 recognizes multiple epitopes of the MAGE-A antigen superfamily in several types of cancer. J Immunol 186(2): 685-696.

Cho HI, Jung SH, Sohn HJ, Celis E, Kim TG (2015a) An optimized peptide vaccine strategy capable of inducing multivalent $\mathrm{CD} 8+\mathrm{T}$-cell responses with potent antitumor effects. Oncoimmunology 4(11): e1043504.

Cho SG, Kim N, Sohn HJ, Lee SK, Oh ST, Lee HJ, Cho HI, Yim HW, Jung SE, Park G, Oh JH, Choi BO, Kim SW, Kim SW, Chung NG, Lee JW, Hong YS, Kim TG (2015b) Long-term outcome of extranodal NK/T-cell lymphoma patients treated with postremission therapy using EBV LMP1 and LMP2a-specific CTLs. Mol Ther 23(8): 1401-1409.

Cohen CJ, Zhao Y, Zheng Z, Rosenberg SA, Morgan RA (2006) Enhanced antitumor activity of murine-human hybrid T-cell receptor (TCR) in human lymphocytes is associated with improved pairing and TCR/CD3 stability. Cancer Res 66(17): 8878-8886.

Corse E, Gottschalk RA, Allison JP (2011) Strength of TCR-peptide/MHC interactions and in vivo T-cell responses. J Immunol 186(9): 5039-5045.

Davis JL, Theoret MR, Zheng Z, Lamers CH, Rosenberg SA, Morgan RA (2010) Development of human anti-murine T-cell receptor antibodies in both responding and nonresponding patients enrolled in TCR gene therapy trials. Clin Cancer Res 16(23): 5852-5861.

Demachi-Okamura A, Ito Y, Akatsuka Y, Tsujimura K, Morishima Y, Takahashi T, Kuzushima K (2006) Epstein-Barr virus (EBV) latent membrane protein-1-specific cytotoxic T lymphocytes targeting EBVcarrying natural killer cell malignancies. Eur J Immunol 36(3): 593-602.

Duraiswamy J, Sherritt M, Thomson S, Tellam J, Cooper L, Connolly G, Bharadwaj M, Khanna R (2003) Therapeutic LMP1 polyepitope vaccine for EBV-associated Hodgkin disease and nasopharyngeal carcinoma. Blood 101(8): 3150-3156.

Fogg M, Murphy JR, Lorch J, Posner M, Wang F (2013) Therapeutic targeting of regulatory T-cells enhances tumor-specific CD8 + T-cell responses in Epstein-Barr virus associated nasopharyngeal carcinoma. Virology 441(2): 107-113.

Fogg MH, Wirth LJ, Posner M, Wang F (2009) Decreased EBNA-1-specific CD8 + T-cells in patients with Epstein-Barr virus-associated nasopharyngeal carcinoma. Proc Natl Acad Sci USA 106(9): 3318-3323.

Frumento G, Zheng Y, Aubert G, Raeiszadeh M, Lansdorp PM, Moss P, Lee SP, Chen FE (2013) Cord blood T-cells retain early differentiation phenotype suitable for immunotherapy after TCR gene transfer to confer EBV specificity. Am J Transplant 13(1): 45-55.

Gandhi MK, Moll G, Smith C, Dua U, Lambley E, Ramuz O, Gill D, Marlton P, Seymour JF, Khanna R (2007) Galectin-1 mediated suppression of Epstein-Barr virus specific T-cell immunity in classic Hodgkin lymphoma. Blood 110(4): 1326-1329.

Goff SL, Johnson LA, Black MA, Xu H, Zheng Z, Cohen CJ, Morgan RA, Rosenberg SA, Feldman SA (2010) Enhanced receptor expression and in vitro effector function of a murine-human hybrid MART-1-reactive T-cell receptor following a rapid expansion. Cancer Immunol Immunother 59(10): 1551-1560.

Gottschalk S, Edwards OL, Sili U, Huls MH, Goltsova T, Davis AR, Heslop HE, Rooney CM (2003) Generating CTLs against the subdominant Epstein-Barr virus LMP1 antigen for the adoptive immunotherapy of EBV-associated malignancies. Blood 101(5): 1905-1912.

Gottschalk S, Heslop HE, Rooney CM (2005) Adoptive immunotherapy for EBV-associated malignancies. Leuk Lymphoma 46(1): 1-10.

Graham JP, Arcipowski KM, Bishop GA (2010) Differential B-lymphocyte regulation by $\mathrm{CD} 40$ and its viral mimic, latent membrane protein 1 . Immunol Rev 237(1): 226-248.

Grupp SA, Kalos M, Barrett D, Aplenc R, Porter DL, Rheingold SR, Teachey DT, Chew A, Hauck B, Wright JF, Milone MC, Levine BL, June CH (2013) Chimeric antigen receptor-modified T-cells for acute lymphoid leukemia. $N$ Engl J Med 368(16): 1509-1518.

Hammerschmidt W, Sugden B, Baichwal VR (1989) The transforming domain alone of the latent membrane protein of Epstein-Barr virus is toxic to cells when expressed at high levels. J Virol 63(6): 2469-2475.

Hinrichs CS, Borman ZA, Cassard L, Gattinoni L, Spolski R, Yu Z, Sanchez-Perez L, Muranski P, Kern SJ, Logun C, Palmer DC, Ji Y, Reger RN, Leonard WJ, Danner RL, Rosenberg SA, Restifo NP (2009) Adoptively transferred effector cells derived from naive rather than central memory CD8 + T-cells mediate superior antitumor immunity. Proc Natl Acad Sci USA 106(41): 17469-17474.
Johnson LA, Morgan RA, Dudley ME, Cassard L, Yang JC, Hughes MS, Kammula US, Royal RE, Sherry RM, Wunderlich JR, Lee CC, Restifo NP, Schwarz SL, Cogdill AP, Bishop RJ, Kim H, Brewer CC, Rudy SF, VanWaes C, Davis JL, Mathur A, Ripley RT, Nathan DA, Laurencot CM, Rosenberg SA (2009) Gene therapy with human and mouse T-cell receptors mediates cancer regression and targets normal tissues expressing cognate antigen. Blood 114(3): 535-546.

Kanemitsu N, Isobe Y, Masuda A, Momose S, Higashi M, Tamaru J, Sugimoto K, Komatsu N (2012) Expression of Epstein-Barr virus-encoded proteins in extranodal NK/T-cell Lymphoma, nasal type (ENKL): differences in biologic and clinical behaviors of LMP1-positive and -negative ENKL. Clin Cancer Res 18(8): 2164-2172.

Khanna R, Burrows SR, Nicholls J, Poulsen LM (1998) Identification of cytotoxic T-cellepitopes within Epstein-Barr virus (EBV) oncogene latent membrane protein 1 (LMP1): evidence for HLA A2 supertype-restricted immune recognition of EBV-infected cells by LMP1-specific cytotoxic T lymphocytes. Eur J Immunol 28(2): 451-458.

Lee DW, Kochenderfer JN, Stetler-Stevenson M, Cui YK, Delbrook C, Feldman SA, Fry TJ, Orentas R, Sabatino M, Shah NN, Steinberg SM, Stroncek D, Tschernia N, Yuan C, Zhang H, Zhang L, Rosenberg SA, Wayne AS, Mackall CL (2015) T-cells expressing CD19 chimeric antigen receptors for acute lymphoblastic leukaemia in children and young adults: a phase 1 dose-escalation trial. Lancet 385(9967): 517-528.

Li J, Zeng XH, Mo HY, Rolen U, Gao YF, Zhang XS, Chen QY, Zhang L, Zeng MS, Li MZ, Huang WL, Wang XN, Zeng YX, Masucci MG (2007) Functional inactivation of EBV-specific T-lymphocytes in nasopharyngeal carcinoma: implications for tumor immunotherapy. PLoS One 2(11): e1122.

Mitsuyasu RT, Anton PA, Deeks SG, Scadden DT, Connick E, Downs MT, Bakker A, Roberts MR, June CH, Jalali S, Lin AA, Pennathur-Das R, Hege KM (2000) Prolonged survival and tissue trafficking following adoptive transfer of CD4zeta gene-modified autologous CD4 $(+)$ and CD8 $(+)$ T-cells in human immunodeficiency virus-infected subjects. Blood 96(3): 785-793.

Morgan RA, Chinnasamy N, Abate-Daga D, Gros A, Robbins PF, Zheng Z, Dudley ME, Feldman SA, Yang JC, Sherry RM, Phan GQ, Hughes MS, Kammula US, Miller AD, Hessman CJ, Stewart AA, Restifo NP, Quezado MM, Alimchandani M, Rosenberg AZ, Nath A, Wang T, Bielekova B, Wuest SC, Akula N, McMahon FJ, Wilde S, Mosetter B, Schendel DJ, Laurencot CM, Rosenberg SA (2013) Cancer regression and neurological toxicity following anti-MAGE-A3 TCR gene therapy. $J$ Immunother 36(2): 133-151.

Morgan RA, Dudley ME, Wunderlich JR, Hughes MS, Yang JC, Sherry RM, Royal RE, Topalian SL, Kammula US, Restifo NP, Zheng Z, Nahvi A, de Vries CR, Rogers-Freezer LJ, Mavroukakis SA, Rosenberg SA (2006) Cancer regression in patients after transfer of genetically engineered lymphocytes. Science 314(5796): 126-129.

Orentas RJ, Roskopf SJ, Nolan GP, Nishimura MI (2001) Retroviral transduction of a T-cell receptor specific for an Epstein-Barr virusencoded peptide. Clin Immunol 98(2): 220-228.

Parkhurst MR, Yang JC, Langan RC, Dudley ME, Nathan DA, Feldman SA, Davis JL, Morgan RA, Merino MJ, Sherry RM, Hughes MS, Kammula US, Phan GQ, Lim RM, Wank SA, Restifo NP, Robbins PF, Laurencot CM, Rosenberg SA (2011) T-cells targeting carcinoembryonic antigen can mediate regression of metastatic colorectal cancer but induce severe transient colitis. Mol Ther 19(3): 620-626.

Porter DL, Levine BL, Kalos M, Bagg A, June CH (2011) Chimeric antigen receptor-modified T-cells in chronic lymphoid leukemia. $N$ Engl J Med 365(8): 725-733.

Pratt ZL, Zhang J, Sugden B (2012) The latent membrane protein 1 (LMP1) oncogene of Epstein-Barr virus can simultaneously induce and inhibit apoptosis in B cells. J Virol 86(8): 4380-4393.

Rapoport AP, Stadtmauer EA, Binder-Scholl GK, Goloubeva O, Vogl DT, Lacey SF, Badros AZ, Garfall A, Weiss B, Finklestein J, Kulikovskaya I, Sinha SK, Kronsberg S, Gupta M, Bond S, Melchiori L, Brewer JE, Bennett AD, Gerry AB, Pumphrey NJ, Williams D, Tayton-Martin HK, Ribeiro L, Holdich T, Yanovich S, Hardy N, Yared J, Kerr N, Philip S, Westphal S, Siegel DL, Levine BL, Jakobsen BK, Kalos M, June CH (2015) NY-ESO-1-specific TCR-engineered T-cells mediate sustained antigenspecific antitumor effects in myeloma. Nat Med 21(8): 914-921.

Rasmussen AM, Borelli G, Hoel HJ, Lislerud K, Gaudernack G, Kvalheim G, Aarvak T (2010) Ex vivo expansion protocol for human tumor specific T-cells for adoptive T-celltherapy. J Immunol Methods 355(1-2): 52-60. 
Riddell SR, Greenberg PD (1995) Principles for adoptive T-cell therapy of human viral diseases. Annu Rev Immunol 13: 545-586.

Robbins PF, Morgan RA, Feldman SA, Yang JC, Sherry RM, Dudley ME, Wunderlich JR, Nahvi AV, Helman LJ, Mackall CL, Kammula US, Hughes MS, Restifo NP, Raffeld M, Lee CC, Levy CL, Li YF, El-Gamil M, Schwarz SL, Laurencot C, Rosenberg SA (2011) Tumor regression in patients with metastatic synovial cell sarcoma and melanoma using genetically engineered lymphocytes reactive with NY-ESO-1. J Clin Oncol 29(7): 917-924.

Rodriguez F, Slifka MK, Harkins S, Whitton JL (2001) Two overlapping subdominant epitopes identified by DNA immunization induce protective CD8(+ ) T-cell populations with differing cytolytic activities. J Virol 75(16): 7399-7409.

Rosati SF, Parkhurst MR, Hong Y, Zheng Z, Feldman SA, Rao M, Abate-Daga D, Beard RE, Xu H, Black MA, Robbins PF, Schrump DA, Rosenberg SA, Morgan RA (2014) A novel murine T-cell receptor targeting NY-ESO-1. J Immunother 37(3): 135-146.

Rosenberg SA, Restifo NP, Yang JC, Morgan RA, Dudley ME (2008) Adoptive cell transfer: a clinical path to effective cancer immunotherapy. Nat Rev Cancer 8(4): 299-308.

Rosenberg SA, Yang JC, Sherry RM, Kammula US, Hughes MS, Phan GQ, Citrin DE, Restifo NP, Robbins PF, Wunderlich JR, Morton KE, Laurencot CM, Steinberg SM, White DE, Dudley ME (2011) Durable complete responses in heavily pretreated patients with metastatic melanoma using T-cell transfer immunotherapy. Clin Cancer Res 17(13): $4550-4557$.

Savoldo B, Rooney CM, Di Stasi A, Abken H, Hombach A, Foster AE, Zhang L, Heslop HE, Brenner MK, Dotti G (2007) Epstein Barr virus specific cytotoxic $\mathrm{T}$ lymphocytes expressing the anti-CD30zeta artificial chimeric T-cell receptor for immunotherapy of Hodgkin disease. Blood 110(7): 2620-2630.

Schaft N, Lankiewicz B, Drexhage J, Berrevoets C, Moss DJ, Levitsky V, Bonneville M, Lee SP, McMichael AJ, Gratama JW, Bolhuis RL, Willemsen R, Debets R (2006) T-cell re-targeting to EBV antigens following TCR gene transfer: CD28-containing receptors mediate enhanced antigen-specific IFNgamma production. Int Immunol 18(4): 591-601.

Schneck JP (2000) Monitoring antigen-specific T-cells using MHC-Ig dimers. Immunol Invest 29(2): 163-169.

Shaffer DR, Savoldo B, Yi Z, Chow KK, Kakarla S, Spencer DM, Dotti G, Wu MF, Liu H, Kenney S, Gottschalk S (2011) T-cells redirected against CD70 for the immunotherapy of CD70-positive malignancies. Blood 117(16): 4304-4314.
Smith C, Cooper L, Burgess M, Rist M, Webb N, Lambley E, Tellam J, Marlton P, Seymour JF, Gandhi M, Khanna R (2006) Functional reversion of antigen-specific CD8 + T-cells from patients with Hodgkin lymphoma following in vitro stimulation with recombinant polyepitope. J Immunol 177(7): 4897-4906.

Straathof KC, Leen AM, Buza EL, Taylor G, Huls MH, Heslop HE, Rooney CM, Bollard CM (2005) Characterization of latent membrane protein 2 specificity in CTL lines from patients with EBV-positive nasopharyngeal carcinoma and lymphoma. J Immunol 175(6): 4137-4147.

Ueno T, Fujiwara M, Tomiyama H, Onodera M, Takiguchi M (2004) Reconstitution of anti-HIV effector functions of primary human CD8 T lymphocytes by transfer of HIV-specific alphabeta TCR genes. Eur J Immunol 34(12): 3379-3388.

van Loenen MM, de Boer R, Amir AL, Hagedoorn RS, Volbeda GL, Willemze R, van Rood JJ, Falkenburg JH, Heemskerk MH (2010) Mixed T-cell receptor dimers harbor potentially harmful neoreactivity. Proc Natl Acad Sci USA 107(24): 10972-10977.

Woll MM, Fisher CM, Ryan GB, Gurney JM, Storrer CE, Ioannides CG, Shriver CD, Moul JW, McLeod DG, Ponniah S, Peoples GE (2004) Direct measurement of peptide-specific CD8 + T-cells using HLA-A2:Ig dimer for monitoring the in vivo immune response to a HER2/neu vaccine in breast and prostate cancer patients. J Clin Immunol 24(4): 449-461.

Xue SA, Gao L, Ahmadi M, Ghorashian S, Barros RD, Pospori C, Holler A, Wright G, Thomas S, Topp M, Morris EC, Stauss HJ (2013) Human MHC Class I-restricted high avidity CD4 + T-cells generated by co-transfer of TCR and CD8 mediate efficient tumor rejection in vivo. Oncoimmunology 2(1): e22590.

Yamamoto R, Nishikori M, Kitawaki T, Sakai T, Hishizawa M, Tashima M, Kondo T, Ohmori K, Kurata M, Hayashi T, Uchiyama T (2008) PD-1-PD1 ligand interaction contributes to immunosuppressive microenvironment of Hodgkin lymphoma. Blood 111(6): 3220-3224.

Zheng Y, Parsonage G, Zhuang X, Machado LR, James CH, Salman A, Searle PF, Hui EP, Chan AT, Lee SP (2015) Human leukocyte antigen (HLA) $A^{\star} 1101$-restricted Epstein-Barr virus-specific T-cell receptor gene transfer to target nasopharyngeal carcinoma. Cancer Immunol Res 3(10): $1138-1147$.

This work is published under the standard license to publish agreement. After 12 months the work will become freely available and the license terms will switch to a Creative Commons AttributionNonCommercial-Share Alike 4.0 Unported License.

Supplementary Information accompanies this paper on British Journal of Cancer website (http://www.nature.com/bjc) 